[23] Sorokina, O. N. (2004). The state of masticatory muscles in modeling the mandibular deformity during the period of its active growth. Novosibirsk, 23.

[24] Murphy, E., Williams, G. R. (2004). The thyroid and the skeleton. Clinical Endocrinology, 61 (3), 285-298. doi: http://doi.org/10.1111/j.1365-2265.2004.02053.x

[25] Mi, Y. F., Li, X. Y., Tang, L. J. (2009). Improvement in cardiac function after sarcoplasmic reticulum $\mathrm{Ca}^{2+}$ ATPase gene transfer in a beagle heart failure model. Chinese Medical Journal, 122 (12), $1423-1428$.

\title{
MEDICAL GENETIC COUNSELING OF WOMEN WITH CONGENITAL HEART DISEASES OF FETUS
}

\author{
Yevheniya Sharhorodska \\ Department of Clinical Genetics \\ Institute of Hereditary Pathology of the National Academy of Medical Sciences of Ukraine \\ 31 A Lysenko str., Lviv, Ukraine, 79008 \\ gendoctor86@gmail.com \\ Nadiya Helner \\ Medical genetic center \\ Institute of Hereditary Pathology of the National Academy of Medical Sciences of Ukraine \\ 31 A Lysenko str., Lviv, Ukraine, 79008 \\ Natalia Prokopchuk \\ Medical genetic center \\ Institute of Hereditary Pathology of the National Academy of Medical Sciences of Ukraine \\ 31 A Lysenko str., Lviv, Ukraine, 79008 \\ prokopchuk-natalia@ukr.net \\ Halyna Makukh \\ Genetic laboratory \\ Institute of Hereditary Pathology of the National Academy of Medical Sciences of Ukraine \\ 31 A Lysenko str., Lviv, Ukraine, 79008 \\ makukh_halyna@ukr.net
}

\begin{abstract}
Aim of the work. Determine the effectiveness of prenatal diagnosis of congenital heart defects in the fetus and the informativeness of different markers used in the medical-genetic counseling of pregnant women..

Materials and methods. The analysis of the results of medical genetic counseling of pregnant women with fetal heart diseases was carried out. The effectiveness of using different methods of prenatal diagnosis in 67 pregnant women is estimated. The data of somatic, genealogical and reproductive anamnesis, biochemical markers of chromosomal pathology of the 1st and 2nd trimester of pregnancy, and the spectrum of the detected fetal heart disease were studied.

Results of the research. It was found that $46(68.7 \%)$ women had somatic diseases: pathology of the cardiovascular system $(11.9 \%)$; endocrine system - at 8 (11,9\%); respiratory disease - $3(4.5 \%)$ and urinary system - $2(3.0 \%) .13(19.4 \%)$ out of 67 women had acute respiratory viral infections in the first trimester of pregnancy. In 4 (6\%) cases - bad habits. The first time pregnant were $31(46.3 \%)$ women, $21(31.3 \%)$ - the second time, $10(14.9 \%)$ in the third, and $5(7.5 \%)$ in the fourth or more times. In history, $58(86.6 \%)$ women did not have reproductive function disorders, $8(11.9 \%)$ had unauthorized miscarriages and frozen pregnancy. The burden of gynecological anamnesis was observed in 12 (17.9\%) women, and hereditary - in 6 ( $9.0 \%)$ women. In the structure of congenital defects of the heart, false anatomical anomalies were found more often: hypoplasia of the left heart organs - 14 (20.9\%), tetralogy of Fallot - 9 (13.3\%). Biochemical markers of chromosomal pathology in the first trimester in $11(16.4 \%)$ women recorded indicators that are characteristic of the risk of chromosomal pathology, and in the second trimester - in 9 (13.4\%). Two pregnant women used a NIPT (non-invasive prenatal test) test that did not detect chro-
\end{abstract}


mosomal abnormalities in the fetus. In 8 cases, invasive prenatal diagnosis of the fetus was recommended, which was carried out by three women, and five refused.

Conclusions. The peculiarities of somatic (in 46-68.7\% of women), reproductive (in 8-11.9 \% of women) gynecological anamnesis (in 12-17.9\% of women), which can be the risk factors of congenital fetal heart disease, are revealed. In the structure of congenital defects of the heart of the fetus more often revealed hypoplasia of the left heart organs - 14 (20.9 \%), tetralogy of Fallot $9(13.3 \%)$. In $11(16.4 \%)$ women recorded indicators of biochemical markers, characteristic for the risk of chromosomal pathology, in the first trimester, and - in $9(13.4 \%)$ pregnant women - in the second trimester. Comparative data on prenatal diagnosis of congenital heart defects in the fetus of chromosomal, monogenic and multifactorial etiology are given. On the basis of the obtained results an algorithm of medical-genetic counseling of this contingent of patients was offered.

Keywords: prenatal diagnosis, medical genetic counseling, congenital heart defects.

\section{Introduction}

The incidence of congenital heart defect (CHD) in the world ranges from 10 to 13 cases per 1,000 children born alive $[1,2]$. In Ukraine, the average CHD frequency ranges from 8-9 to 11-13 cases per 1,000 live births [3, 4]. CHD make up the majority of congenital fetal pathology. The basis for early detection of any congenital malformations is well organized screening of pregnant women. In many countries, fetal echocardiography is a routine method of study for all pregnant women $[5,6]$. However, the experience of foreign colleagues shows that even with complex cardiac anomalies (such as full form atrioventricular channel or hypoplasy of left part of the heart), suspected heart defect occurs only in half of cases [7]. Medium CHD detection rate in the prenatal period in Western Europe is $19-49 \%$, in Eastern $-8 \%[8,9]$. There is no exact data on these indicators in Ukraine. There is insufficient data on the algorithms of medical genetic counseling, since a significant part in the etiology of CHD is chromosomal or monogenic etiology. In Ukraine, moreover, there is the lack of high-tech equipment and qualified doctors in fetal cardiology; they require constant improvement and there is insufficient coverage of pregnant women with ultrasound screening $[10,11]$.

Reduce the incidence of congenital malformations can be achieved by individual prevention of congenital heart disease (prevention of preconception and prenatal diagnostics), CHD monitoring frequency and definition of negative risk factors incurred. Prenatal diagnosis reveals about $49 \%$ of heart disease in the fetus, and helps to optimize the results of surgical correction of complex CHD in newborns and infants $[12,13]$.

Methods of prenatal diagnosis are divided into indirect when the object is a pregnant woman, and straight when doctor study fetus. It should be noted that the main purpose of indirect methods - selection of women at high risk for further in-depth observation and medical genetic counseling.

Medical genetic counseling (MGC) is an important part of every stage of the system of preventive measures, a prerequisite for the effective functioning of which is cooperation among specialists in genetic monitoring system.

At present, the only way to reduce congenital and hereditary diseases is preventive measures, which are distributed in stages:

a) prevention preconception that includes, besides readjustment family when planning pregnancy, measures to reduce exposure to controlled environmental factors;

b) prenatal diagnosis of congenital and hereditary diseases of the fetus, which provides detection of fetuses with congenital disorders and hereditary disease, followed by surgical correction;

c) screening massive and selective programs among newborns that can detect certain pathological conditions and provide adequate medical care to sick children;

d) early surgical correction of birth defects $[14,15]$.

Non-invasive methods for prenatal diagnosis are used widely and include: triple ultrasound evaluation of the mandatory ultrasound markers of chromosomal aberrations (collar area, the size of the nasal bone, Doppler venous duct in the first trimester, the thickness of the neck fold ratio of femur length biparietal to size, etc.) and determination of serum biochemical markers of pregnant 
(PAPP - protein (associated with pregnancy plasma protein-A), $\beta$ hCG (B-subunit of human chorionic gonadotropin) in the first trimester and $\alpha \mathrm{FP}$ (alfa-fetoprotein) hCG, unconjugated estriol - in the second trimester).

It is believed that the result of prenatal ultrasound is affected mainly with technical reasons (resolution device, the pregnancy, the thickness of the anterior abdominal wall of the mother, the position and size of the fetus, the drug experience). However, a significant role to play also features the formation and various hemodynamic CHD. Despite the fact that the anatomical details of the fetal heart can be seen from 12-14 weeks, various manifestations can vary significantly CHD that determines the timing of diagnosis $[16,17]$.

Researchers in majority of countries have concluded that identify the structure of the heart can have 14 weeks of pregnancy [18]. However, the optimal gestational time to study the cardiovascular system of the fetus after 20-22 weeks of pregnancy. During this period, complex structural abnormalities of the heart reveal, such as ventricular hypoplasia or large artery wall hypertrophy ventricular atrial enlargement $[14,18]$. In addition, according to many authors, early studies of the heart of the fetus at 14 weeks does not always give an adequate picture of cardiovascular disease, as the growth of cardiac structures takes place for the duration of pregnancy (from aortic stenosis until critical stenosis of the aorta, leading to atresia and ends hypoplastic syndrome) [18].

Given that the prognosis, treatment approaches, and CHD primary prevention of fetal malformations affect etiology, chromosomal, monogenic or multifactorial origins, an important issue is the MGC detection algorithm of heart defects in the fetus. Conflicting data are available on the relationship of frequency and structure of prenatally detected CHD with chromosomal disorders $[19,20]$. Need to optimize diagnostic methods for determining the etiology of heart disease is already present in the prenatal period. Therefore, the relevant issue is the elaboration of approaches to medical genetic counseling this group of women, and to develop recommendations for the prevention of CHD in the fetus.

Against the background of reduced fertility and increased mortality in Ukraine, including a child, growing morbidity and disability of children associated with CHD (40-50\% of perinatal mortality and morbidity by $30 \%$ ) [21, 22], acquires relevance the need for effective prevention of $\mathrm{CHD}$, timely and adequate prenatal testing and development (improvement) algorithms of MGC unified with CHD fetus.

\section{Aim of the research}

Determine the effectiveness of prenatal diagnosis, information of various markers of congenital heart defects in the fetus and to propose an algorithm of medical genetic counseling of this pregnant women population.

\section{Materials and methods}

We analyzed data cards of pregnant women, who gave birth to children with CHD for period of 5 years (2011-2015) in the Lviv regional clinical hospital and medical genetic counseling results of 67 pregnant women aged 18-42 years (average age amounted to 26.8 \pm 6.6 ) diagnosed with fetal heart defects that are addressed in Medical Genetics center SI "Institute of genetic pathology Medical Sciences of Ukraine (MGC), in Lviv on suspicion of fetal CHD for the period 2011-2015 and changes in biochemical screening markers during pregnancy. The criterion for inclusion in the group was having a baby with a clinical diagnosis "Congenital heart defect" according to ICD-10 (Q20-Q28 Congenital malformations of the circulatory system) and the availability of medical genetic conclusion during pregnancy. During the work, we evaluated the effectiveness of different methods of prenatal diagnosis in 67 pregnant women with CHD fetus, which had ultrasound fetal diagnosis of CHD that was made prenatally, studied data of physical, family and reproductive history, biochemical markers and second trimester of pregnancy, and spectrum of the detected heart disease in the fetus. Statistical analysis of the results was performed by the method of variation statistics using computer programs "Statistica 6.0" and "Excel 5.0". 


\section{Results of the research}

The program of medical and genetic counseling of pregnant women with diagnosed fetal heart defects found prenatally, studied somatic, reproductive history and genealogy. It was found that $21(31.3 \pm 0.04 \%)$ women had a physical illness, such as pathology of the cardiovascular system $-8(11.9 \pm 0.04 \%)$, of which $1(1.5 \pm 0.01 \%)$ woman had mitral valve prolapse, $5(7.5 \pm 0.06 \%)-$ varicose veins of the lower extremities, $2(3.0 \pm 0.02 \%)$ - hypertension; endocrine system $8(11.9 \pm 0.04 \%)$, of which $2(3.0 \pm 0.02 \%)$ women had obesity, $1(1.5 \pm 0.01 \%)$ - diabetes type 1 , and $5(7,5 \pm 0,04 \%)$ - hyperplasia of the thyroid gland. The number of women diagnosed with the respiratory disease (chronic bronchitis) and urinary tract (chronic pyelonephritis) $-3(4.5 \pm 0.03 \%)$ and $2(3.0 \pm 0.02 \%)$.

It was found that 13 of 67 women $(19.4 \pm 0.03 \%)$ suffered acute respiratory viral infection in the first-second trimester and $1(1.5 \pm 0.01 \%)$ woman suffered measles. In $4(6.0 \pm 0.03 \%)$ pregnant we marked bad habits: 3 - (4.5 $\pm 0.02 \%)$ - smoking, $1(1.5 \pm 0.01 \% \%)$ - had professional activities connected with varnishes and paints.

Almost half of the women were pregnant for the first time - $31(46.3 \pm 0.04 \%), 21(31.3 \pm$ $\pm 0.04 \%)$ - in the second time, $10(14.9 \pm 0.02 \%)$ in the third and $5(7.5 \pm 0.04 \%)$ in four or more times.

Most women - $58(86.6 \pm 0.04 \%)$ reproductive patient had no history. Only $8(11.9 \pm 0.04 \%)$ patients were observed before this pregnancy and spontaneous abortions sank pregnancy, and previous pregnancy of one woman was complicated by fetal congenital disorders (hydrocephalus and cerebrospinal hernia).

Violation of gynecologic history was observed in $12(17.9 \pm 0.01 \%)$ of this group of pregnant women 10 (14.9 $\pm 0.02 \%)$ before pregnancy had chronic inflammatory gynecological diseases, 2 $(3.0 \pm 0.02 \%)$ - ovarian cysts. In one woman $(1.5 \pm 0.01 \%)$ the pregnancy was the result of IVF (in vitro fertilization).

In the study of family history of CHD female fetus we found that heredity was burdened in $6(9.0 \pm 0.05 \%)$ women, $2(3.0 \pm 0.02 \%)$ women had congenital anomalies of the urinary system, $1(1.5 \pm 0.01 \%)$ case of congenital deafness, congenital cataracts, hereditary hypertension, cerebral palsy unknown etiology.

All 67 women experimental group were registered in antenatal clinics in the place of the residence.

Study of the CHD structure, who were diagnosed prenatally according to the conclusions of Medical Genetic Center obtained from the analysis of medical records route from studying the history of newborns with CHD, cards pregnant found that often are identified gross anatomical anomalies such as hypoplasy of left part of the heart - $14(20.9 \pm 0.01 \%)$, tetralogy of Fallot $9(13.3 \pm 0.03 \%)$ and large defects, ventricular septal defect (VSD) + atrial septal defect (ASD) + open oval window $(\mathrm{OOW})+$ patent ductus arteriosus $(\mathrm{PDA})-9(13.3 \pm 0.03 \%)$.

The analysis of the diagnostic date for CHD in the fetus showed that only one patient $(1.5 \pm 0.04 \%)$ CHD (tetralogy of Fallot) was detected in the first trimester of pregnancy, in $24(35.8 \pm 0.02 \%)$ women - in II trimester and, unfortunately, in most cases $-42(62.7 \pm 0.02 \%)$, this pathology was diagnosed in the third trimester of pregnancy. The latter limited the diagnostic capabilities of specialists, the timely conduct of a prenatal consultation to determine the tactics, method and place of delivery, as well as the psychological preparation of a pregnant woman.

Considering that, the prognosis of the course approaches to treatment, and the main further prevention and prediction of CHD in the fetus affects the etiology of the defect: chromosomal, monogenic or multifactorial genesis, analyzed the differences that affect the tactics of MGC for this contingent of patients.

Diagnostic methods that we recommend to include in the algorithm of medical-genetic counseling of CHD, depending on the etiology, are shown in Table $\mathbf{1 .}$

Conflicting is the data on the association of the frequency and structure of prenatal CHD detected with chromosomal pathology [19, 20]. Diagnostic methods for determining the etiology of heart defects already in the prenatal period are required to optimize. Therefore, the urgent question is the elaboration of approaches to the medical-genetic counseling of such a contingent of women, as well as the development of recommendations for the prevention of CHD in the fetus. 
To exclude the risk of chromosomal diseases in the fetus, a comprehensive study was conducted on the levels of biochemical markers in the 1st and 2nd trimesters of pregnancy. In the first trimester, serum pregnancy levels determined the level of protein A associated with pregnancy (PAPP-A) and the free subunit of chorionic gonadotrophin ( $\beta \mathrm{hCG})$.

Table 1

Diagnostic methods for determination of etiology of CHD with medical genetic advising

\begin{tabular}{|c|c|c|c|}
\hline \multirow[b]{2}{*}{ Indexes } & \multicolumn{3}{|c|}{ Etiology of CHD } \\
\hline & Chromosomal anomalies & Monogene defects & $\begin{array}{l}\text { Multifactori } \\
\text { (including terat }\end{array}$ \\
\hline Examples & $\begin{array}{l}\text { - Down Syndrome } \\
\text { - Edwards } \\
\text { - Patau } \\
\text { - Terner }\end{array}$ & $\begin{array}{c}\text { - VACTERL-association } \\
\text { - Di Joggi } \\
\text { Williams } \\
\text { - Nunan syndrome } \\
\text { - Kabuki syndrome } \\
\text { - Holt-Oram Sidrome }\end{array}$ & $\begin{array}{c}\text { - Isolated def } \\
\text { - MGM }\end{array}$ \\
\hline Postnatal percentage [\%] & $20 \%$ & $10 \%$ & $70 \%$ \\
\hline $\begin{array}{l}\text { Review of fetus heart in I } \\
\text { trimester }\end{array}$ & $\begin{array}{c}\text { Pathological flow in the venous } \\
\text { duct, tricuspid edentural regur- } \\
\text { gitation in } 90 \%\end{array}$ & $\begin{array}{l}\text { Pathological flow in the venous } \\
\text { duct, tricuspid regurgitation }\end{array}$ & $\begin{array}{l}\text { Pathological flow in } \\
\text { duct, tricuspid regur } \\
\text { part of case }\end{array}$ \\
\hline $\begin{array}{l}\text { Other biochemical and ultra- } \\
\text { sound markers }\end{array}$ & $\begin{array}{c}\text { Thickening of collar space, } \\
\text { hypoplasia of the nasal bone } \\
\text { PAPP-A } \downarrow+\beta \text { hCG } \uparrow \\
\alpha \mathrm{FP} \downarrow+\beta \mathrm{hCG}+\mathrm{f}-\mathrm{E} 3 \downarrow \\
\text { in } 90 \%\end{array}$ & $\begin{array}{c}\text { Thickening of collar space - } \\
1-2 \% \\
\text { Biochemical markers are } \\
\text { normal }\end{array}$ & \multirow[b]{2}{*}{$2-9 \%$} \\
\hline $\begin{array}{l}\text { Risk for the following preg- } \\
\text { nancies }\end{array}$ & $\begin{array}{l}5-17 \% \text { (depends on the type } \\
\text { of chromosomal pathology, the } \\
\text { presence of structural changes } \\
\text { in parents) }\end{array}$ & $25 \%$ & \\
\hline $\begin{array}{l}\text { Features of MGC and pre-con- } \\
\text { ceptual prevention }\end{array}$ & $\begin{array}{l}\text { Cariotype of spouses, folic } \\
\text { acid } 5 \mathrm{mg} \text { /day, expert ultra- } \\
\text { sound in I trimester, in the } \\
\text { presence of structural changes } \\
\text { in the karyotype - IPD (am- } \\
\text { niocentesis + fetal karyotype) }\end{array}$ & $\begin{array}{l}\text { Molecular genetic analysis, } \\
\text { DNA sequencing, microarray, } \\
\text { folic acid } 5 \mathrm{mg} / \text { day, expert } \\
\text { ultrasound and trimester, IPD } \\
\text { (chorionic villus sampling) }+ \\
\text { molecular genetic analysis }\end{array}$ & $\begin{array}{r}\text { Folic acid } 5 \mathrm{mg} \text {, avo } \\
\text { harmful factors of th } \\
\text { ment, expert ultrasol } \\
\text { first trimeste }\end{array}$ \\
\hline $\begin{array}{l}\text { The proportion of prenatally } \\
\text { found in this study }\end{array}$ & $\begin{array}{l}\text { Five women were suspected, } \\
\text { but } 5 \text { women refused to } \\
\text { receive IDP }\end{array}$ & \multicolumn{2}{|c|}{$(92 \%)^{*}$} \\
\hline \multicolumn{4}{|c|}{$\begin{array}{l}\text { Note: * These cases need to be verified in the postnatal period; IPD - invasive prenatal diagnosis; MGM - multiple } \\
\text { malformations }\end{array}$} \\
\hline \multicolumn{4}{|c|}{$\begin{array}{l}\text { The highest percentage of women with fetal CHD had an elevated PAPP-A level and a low- } \\
\text { ered } \beta \text { hCG level of } 77.6 \pm 0.01 \% \text {; with a low level (less than } 0.5 \mathrm{MoM} \text { ) of PAPP-A and a low level of } \\
\text { hCG was } 16.4 \pm 0.01 \% \text {, low RARR-A and elevated hCG- } 6.0 \pm 0.01 \% \text {. Pregnant women who found } \\
\text { a lowering of PARR-A in the blood have expanded the complex of prenatal measures in the sec- } \\
\text { ond trimester using invasive methods. Pregnant women who showed increased RARR-A in blood } \\
\text { with a parallel underestimation, a study of levels of biochemical markers in the second trimester } \\
\text { (16-18 weeks) - aFP, hCG, f-E3. Thus, in } 16.4 \pm 0.01 \% \text { of women, the biochemical markers of the } \\
\text { I trimester indicated a risk from the fetus's chromosomal pathology, and such pregnant women } \\
\text { needed further in-depth methods for prenatal diagnosis, which was confirmed by the biochemical } \\
\text { markers of the II trimesters at } 13.4 \pm 0.03 \% \text { of women. }\end{array}$} \\
\hline
\end{tabular}


Thus, a decrease in $\alpha \mathrm{FP}$ with an increase in $\beta$ hCG was observed in $13.4 \pm 0.03 \%$ of women with fetal CHD, an increase in aFP and an understatement of n-E3 in $76.1 \pm 0.01 \%$. An elevated level of aFP (greater than $2.5 \mathrm{MoM}$ ) with a parallel undershot of HG and n-E3 was observed at $10.5 \pm 0.06 \%$. Pregnant women with a reduced aFP level and elevated hCG levels were subsequently recommended for invasive prenatal diagnostic (IPD).

To exclude chromosomal pathology, 8 women were recommended for an IPD, which was performed by three women. Two pregnant women conducted a NIPT test - an analysis of a fetal karyotype of maternal blood that did not detect chromosomal abnormalities. Five pregnant women refused to conduct an invasive PD. Of the 67 women, 9 were counseled at the National Institute of Cardiovascular Surgery named after M. M. Amosov or in the "Scientific and Practical Medical Center for Pediatric Cardiology and Cardiology" of the Ministry of Health of Ukraine for the development of the tactics of delivery and postnatal correction of congenital heart defect of a newborn child.

On the basis of the obtained results, an algorithm of medical-genetic counseling of women with CHD in the fetus is proposed in the prenatal, postnatal and subsequent pre-conceptional stages (Fig. 1).

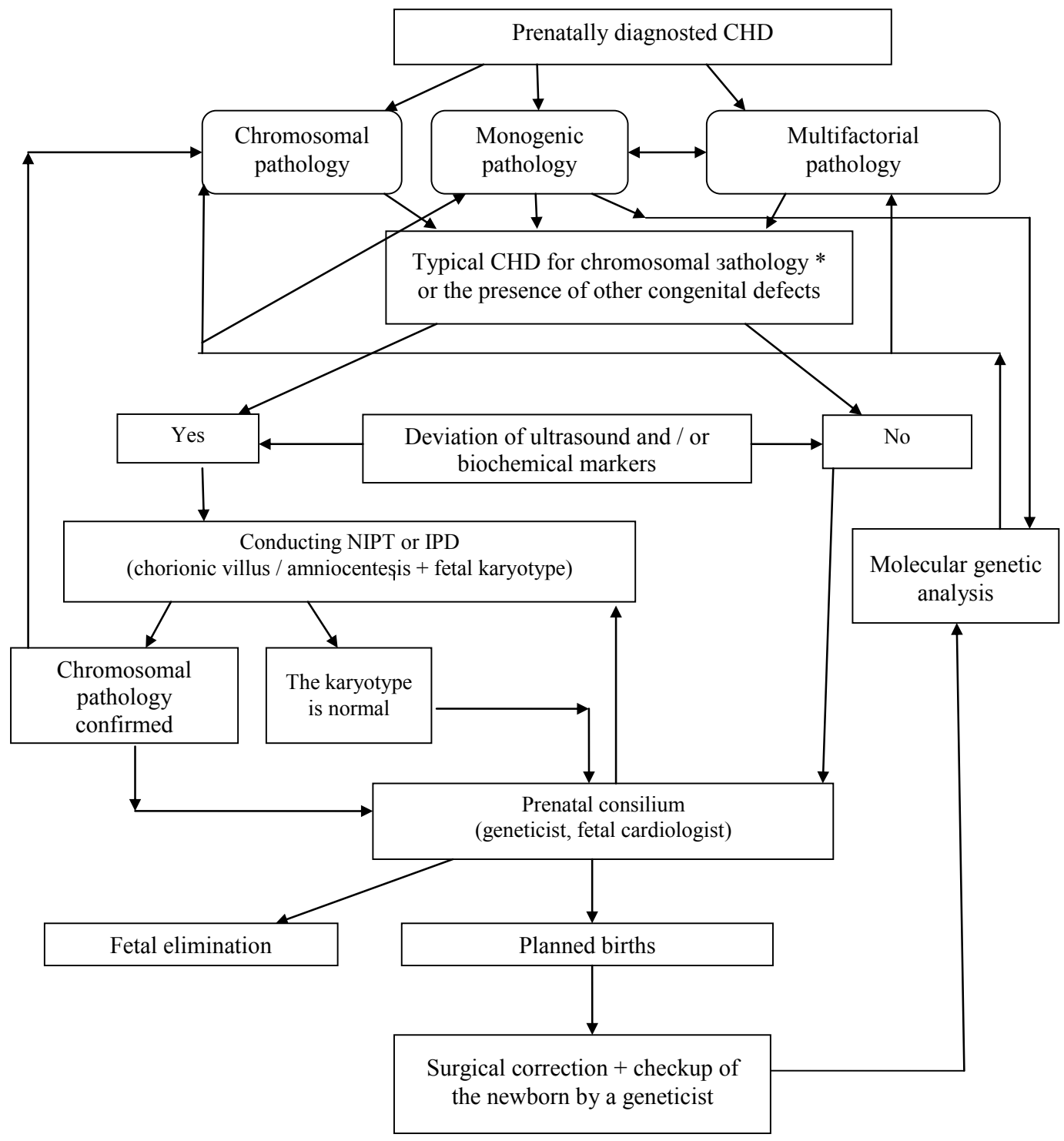

* AV-communication, atrial septal defect, ventricular septal defect, artery coarctation

Fig. 1. Algorithm of medical-genetic counseling of women with fetal CHD 


\section{Discussion of the results}

The data obtained by us show that in the structure of the CHD of the fetus more often revealed rude anatomical anomalies, such as hypoplasia of the left heart organs - 14 (20.9\%), tetralogy of Fallot - 9 (13.3\%), and major defects of VSD + VSD + PDA - 9 (13.3\%). However, they were diagnosed with the majority in the third trimester of pregnancy $(62.7 \%)$. The determining factors influencing the accuracy of prenatal diagnosis of CHD are professional qualifications and the quality of visualization. Several researchers are convinced that today all heart defects can be diagnosed, even in the first trimester of pregnancy, but the result of the diagnosis depends on the quality of the ultrasound equipment, professionalism of the specialist [14, 15]. The two-level system of prenatal diagnostics allows to determine with high degree of reliability the congenital malformations of the heart. At the same time, the system does not work efficiently: at present, more than $60 \%$ of birth defects in the heart have been diagnosed only in the third trimester. Since we analyzed the data for 2011-2015, one can hope that at present the level of diagnostics, taking into account the qualifications of specialists and equipment upgrades, is somewhat higher.

To find out the likely factors of increased risk of CHD in the fetus during the medical genetic counseling, data of the features of the somatic, reproductive gynecological history of women who have been diagnosed with fetal CHD during pregnancy were collected and analyzed. Thus, $31.3 \%$ of females with fetal CHD had somatic diseases, the most frequent were cardiovascular (11.9\%) and endocrine (11.9\%). $11.9 \%$ of women had a history of involuntary miscarriage, frozen pregnancy, congenital disorders of the fetus. $17.9 \%$ of women in this group have gynecological disorders: chronic inflammatory diseases, ovarian cysts. These factors may be a potential risk factor for congenital fetal heart disease. However, for the formulation of evidentiary findings, further analysis and comparison of the obtained indicators with the data of the control sample - a group of women who gave birth to healthy children. We assume that individual values regarding the history of women with CHD in the fetus will coincide with the control sample. Complications from somatic, genetic, reproductive history in women may be a risk factor for CHD. Such confirmation was found in the data of Lastivka I. V. et al. [20].

Detection of chromosomal pathology during pregnancy is an important task for prenatal diagnosis. Use of biochemical markers of congenital and chromosomal pathologies of the I and II trimesters in women with congenital heart defects, although it allowed to suspect chromosomal pathology, but unfortunately, did not serve as a sign of CHD in the fetus. Since, for the differentiation of the etiology of CHD, biochemical and ultrasound scoring markers are important for the markers of chromosomal pathology in the fetus, a retrospective analysis of these indices was performed in women with fetal CHD. The biochemical markers of chromosomal pathology, which are defined in the first trimester of pregnancy, were changed in $16.4 \%$ and in the second trimester in $13.4 \%$ of women with congenital heart defects. These women were offered further research to exclude chromosomal abnormalities. In order to exclude chromosomal pathology, women were recommended for an invasive PD, which had been approved by less than half of women, which could be explained by low awareness of this procedure and doubts about possible negative consequences. Many advantages in such cases are the implementation of non-invasive prenatal diagnosis (NIPT) an analysis of the fetal karyotype of the mother's blood. Negative limitation of this analysis is its high cost. Among the women surveyed, this study was conducted in two cases and did not reveal chromosomal abnormalities. Such results allow us to form a positive outlook for the pathology of the fetus, but do not exclude a monogenic defect. We consider compulsory review of genetics after the birth of a child with CHD in order to identify a possible symptom that will indicate monogenous nosology and will require special studies

Five pregnant women refused to conduct an invasive PD. This work also reveals many ethical issues that need to be addressed. The duty of the geneticist is to report to the patients all options for the disease with all possible consequences and to support families in implementing their decision.

An optimized algorithm for medical genetic counseling, presented in Fig. 1, was proposed to improve the system of pre-conceptional prevention and early diagnosis of CHD, effective medico-genetic counseling and prediction of healthy offspring. 
Another important issue is the detection of critical forms of CHD, which will allow in the future to provide cardiologic and cardiac surgery to the child in a timely manner after birth and to avoid tactical mistakes in conducting patients in the neonatal period. About $50 \%$ of cardiac anomalies account for complicated heart defects, in which provision of specialized medical care is necessary in the first days, months, and sometimes in the first hours of the child's life. According to Boguta L. Yu. et all, among children born with heart anomalies, $14 \%$ die in the first week of life, $25 \%$ - during the first month, about $40 \%$ - do not survive during the first year [21]. In addition, most complex CHDs are associated with chromosomal abnormalities, genetic syndromes or multiple developmental abnormalities [14]. This circumstance dictates the need for the earliest possible prenatal detection of this category of $\mathrm{CHD}$, which will make it possible to decide on the most appropriate tactics for the further conduct of pregnancy and the organization of childbirth in specialized maternity hospitals, will provide timely surgical correction of CHD in cardiac surgery clinics. Therefore, some patients in the study group were referred to specialized cardiac surgeries in Ukraine for further assistance.

\section{Conclusions}

1. While medical genetic counseling we found some peculiarities of physical, reproductive gynecological history, which may be the likely risk factors for congenital heart disease of the fetus. Among women with suspected fetal CHD were recorded in $31.3 \%$ of somatic diseases, most of which were cardiovascular pathology (11.9\%) and endocrine systems (11.9\%). In $11.9 \%$ of women had a history of spontaneous abortion, missed abortion, congenital disorders of fetus. $17.9 \%$ of women in this group had gynecological disorders: chronic inflammatory disease, ovarian cysts.

2. The structure of congenital heart defects that are diagnosed in the prenatal period, dominated by gross anatomical abnormalities, hypoplastic left part of the heart (20.9\%), tetralogy of Fallot (13.3\%) and interventricular defects of atrial walls $(13.3 \%)$.

3. In most cases, prenatally detected CHD was diagnosed in the third trimester of pregnancy $-62.7 \%$, in the second trimester $-35.8 \%$, in the first trimester $-1.5 \%$. Late diagnosis of CHD limited the possibilities of specialized professionals timely prenatal consultation to determine the tactics, method and place of delivery, as well as psychological preparation of pregnant women.

4. During the determination of biochemical markers of chromosomal abnormalities in the first trimester, $16.4 \%$ of women with congenital heart disease of the fetus had indicators of risk characteristic chromosomal aberrations and in second trimester that was observed in $13.4 \%$ of women. Because of MGC, 8 women suspected chromosomal etiology of CHD, verified were only 5 , but unfortunately postnatal through rejection of IPA.

5. Based on the results of the algorithm, medical genetic counseling of women with fetal CHD in prenatal, postnatal and further preconception periods.

\section{Referenses}

[1] Kaleschke, G., Baumgartner, H. (2011). Pregnancy in congenital and valvular heart disease. Heart, 97 (21), 1803-1809. doi: http://doi.org/10.1136/heartjnl-2011-300369

[2] Reich, J. D., Haight, D., Reich, Z. S. (2017). A comparison of the incidence of undiagnosed congenital heart disease in hospital born and home born children. Journal of Neonatal-Perinatal Medicine, 10 (1), 71-77. doi: http://doi.org/10.3233/npm-1651

[3] Avramenko, N. V., Nikiforov, O. A., Sukhonos, O. S., Lomeyko, Ye. A., Barkovskiy, D. E., Kabachenko, Ye. V. et. al. (2013). Analiz chastoty obnaruzheniya vrozhdennyh porokov serdca pri provedenii prenatal'noi diagnostiki $\mathrm{v}$ Zaporozhskoi oblasti [AnalysisofthefrequencyofdetectionofcongenitalheartdefectsduringprenataldiagnosisintheZaporozhyeregion]. Zaporozhskiy meditsinskiy zhurnal, 3 (78), 5-8.

[4] Klymenko, T. M., Sorokolat, Yu. V., Karapetyan, O. Yu. (2014). Rezervy vedennya ditej iz vrodzhenymy vadamy sercya [Reserves for the management of children with congenital heart disease]. Perynatologiya y pedyatriya, 2, 106-109.

[5] Pidvysotska, N. I. (2015). Suchasni pryntsypy ta problemy medyko-henetychnoho konsultuvannia [Modern principles and problems of medical genetic counseling]. Klinichna ta eksperymentalna patolohiya, XIV (2 (52)), 244-247. 
[6] Markin, L. B., Medviedieva, O. S. (2013). Udoskonalennia diagnostyky anomalii sertsia plodu pid chas rutynnoho skryningovoho ultrazvukovoho doslidzhennia [Improvement of diagnosis of fetal heart abnormalities during routine screening ultrasonography]. Lvivskyi klinichnyi visnyk, 3 (3), 41-44.

[7] Su, W., Zhu, P., Wang, R., Wu, Q., Wang, M., Zhang, X. et. al. (2016). Congenital heart diseases and their association with the variant distribution features on susceptibility genes. Clinical Genetics, 91 (3), 349-354. doi: http://doi.org/10.1111/cge.12835

[8] Saperova, E. V., Vahlova, I. V. (2017). Congenital Heart Diseases in Children: Incidence, Risk Factors, Mortality. Current Pediatrics, 16 (2), 126-133. doi: http://doi.org/10.15690/vsp.v16i2.1713

[9] Batra, P., Higgins, C., Chao, S. M. (2015). Previous Adverse Infant Outcomes as Predictors of Preconception Care Use: An Analysis of the 2010 and 2012 Los Angeles Mommy and Baby (LAMB) Surveys. Maternal and Child Health Journal, 20 (6), 1170-1177. doi: http://doi.org/10.1007/s10995-015-1904-x

[10] Honchar, M. O., Boichenko, A. D. (2018). Suchasnyi pidkhid do diahnostyky sertsevo-sudynnyh rozladiv u novonarodzhenyh iz hrup perynatalnoho ryzyku $\mathrm{v}$ neonatalnyi period [Modern approach to the diagnosis of cardiovascular disorders in newborns from perinatal risk groups in the neonatal period]. Zdorovia dytyny, 13 (1), 11-21.

[11] Protsiuk, O. V., Lynchak, O. V., Syzonenko, O. V., Pokanevych, T. M. (2013). Vrozhdennye poroki krovoobrashcheniya sredi novorozhdennyh. [Congenital malformations of blood circulation among newborns]. Voprosy prakticheskoi pediatrii, 8 (3), 8-12.

[12] Demidova, N. S., Rybalka, A. N. (2012). Povyshenie ehffektivnosti prenatalnoi diagnostiki vrozhdennyh porokov razvitiya i nasledstvennyh zabolevanii ploda [Increase the efficiency of prenatal diagnosis of congenital malformations and hereditary diseases of the fetus]. Tavricheskii mediko-biologicheskii vestnik, 2 (1), 93-97.

[13] Horbatiuk, O. M., Liaturynska, O. V. (2014). Orhanizatsiia ta perspektyvy rozvytku perynatalnoi dopomohy v Ukraini [Organization and prospects of development of perinatal carein Ukraine]. Neonatolohiya, khirurhiya ta perynatalna medytsyna, IV (4 (14)), 5-10.

[14] Page, J. M., Silver, R. M. (2016). Genetic Causes of Recurrent Pregnancy Loss. Clinical Obstetrics and Gynecology, 59 (3), 498-508. doi: http://doi.org/10.1097/grf.0000000000000217

[15] Njim, T. (2016). Late Pregnancy Outcomes among Women who Attended and Women who did not Attend First Trimester Antenatal Care Visits in a Suburban Regional Hospital in Cameroon. International Journal of MCH and AIDS (IJMA), 5 (1), 14-23. doi: http://doi.org/10.21106/ijma.80

[16] Borelli, M., Baer, R. J., Chambers, C. D., Smith, T. C., Jelliffe-Pawlowski, L. L. (2016). Critical congenital heart defects and abnormal levels of routinely collected first- and second-trimester biomarkers. American Journal of Medical Genetics Part A, 173 (2), 368-374. doi: http://doi.org/10.1002/ajmg.a.38013

[17] Till, S. R., Everetts, D., Haas, D. M. (2015). Incentives for increasing prenatal care use by women in order to improve maternal and neonatal outcomes. Cochrane Database of Systematic Reviews, 12, 2228-2231. doi: http://doi.org/10.1002/14651858.cd009916.pub2

[18] Kovalenko, O. S., Lepokhina, H. S., Zazarkhov, O. Yu., Zlepko, S. M. (2016). Klasyfikatsiia ryzykiv perynatalnoho periodu zhyttia novonarodzhenykh [Classification of the risk of perinatal life of newborns]. Environment \& Health, 4, 52-54.

[19] Connor, J. A., Hinton, R. B., Miller, E. M., Sund, K. L., Ruschman, J. G., Ware, S. M. (2013). Genetic Testing Practices in Infants with Congenital Heart Disease. Congenital Heart Disease, 9 (2), 158-167. doi: http://doi.org/10.1111/chd.12112

[20] Lastivka, I. V., Shvygar, L. V., Sharapa, V. I. (2015). Etiologichni osoblyvosti rozvytku urodzhenyp vad sercya [Etiological features of development of congenital heart defects]. Suchasni tendenciyi rozvytku medychnoyi nauky ta medychnoyi praktyky, 50-52.

[21] Boguta, L. Yu., Rudenko, N. N., Emets, I. N. (2013). Hirurgichne likuvannya vrodzhenyh sercevyh zahvoryuvan u novonarodzhenyh [Surgical Treatment Of Congenital Heart Diseases In Infants]. Sovremennaya Pediatriya, 7, 145-147.

[22] Medvedyev, M. V., Davydova, Yu. V. (2016). Profilaktyka perynatalnyh vtrat: na shlyahu do personalizovanoyi medycyny [Prevention of Perinatal Loss: On the Way to Personalized Medicine]. Perinatologiya i pediatriya, 1 (65), 59-65. 